\author{
Sebastian Konieczny, Ewa Lange, Jolanta Krusiec \\ Katedra Dietetyki, Wydział Nauk o Żywieniu Człowieka i Konsumpcji \\ Szkoła Główna Gospodarstwa Wiejskiego w Warszawie \\ Nowoursynowska 159C, 02-776 Warszawa \\ E-mail: ewa_lange@sggw.pl
}

\title{
WPŁYW DIET ELIMINACYJNYCH NA JAKOŚĆ ŻYCIA OSÓB Z WYBRANYMI CHOROBAMI AUTOIMMUNOLOGICZNYMI
}

\section{WPROWADZENIE}

Choroby autoimmunologiczne stanowia coraz większy problem ze względu na rosnąca liczbę zachorowań i fakt, że sa to schorzenia w dalszym ciagu nieuleczalne. Szacuje się, że $z$ ich powodu cierpi około 3-8\% światowej populacji, $z$ czego $78-85 \%$ chorych to kobiety. Choroby $z$ tej grupy najczęściej ujawniaja się pomiędzy okresem dojrzewania a wiekiem podeszłym (SzCZEBLOWSKA i współaut. 2011). Etiologia większości chorób autoimmunologicznych nie jest jeszcze do końca znana. Do rozwoju autoagresji dochodzi prawdopodobnie na skutek działania wielu czynników, w tym uwarunkowań genetycznych, rozwoju infekcji oraz czynników srodowiskowych takich jak: stres, niektóre leki, promieniowanie UV, dieta, których koincydencja może doprowadzić do rozwoju autoimmunizacji. Przyczyna autoagresji moga być również urazy termiczne, fizyczne, zapalne i wywołane nimi uszkodzenia tkanek, w wyniku czego może dojść do uwalniania autoantygenów (LIS i współaut. 2012, EFFRAIMIDIS i WIERSINGA 2014).

Do najczęstszych chorób autoimmunologicznych należa choroba Hashimoto i celiakia. Choroba Hashimoto to przewlekłe limfocytarne zapalenie tarczycy, które w wyniku immunologicznej odpowiedzi skierowanej przeciwko komórkom pęcherzykowym prowadzi do powstania nacieków limfocytów i uszkodzenia gruczołu tarczowego skutkujacych jego niedoczynnością (AJJAN i WEETMAN 2015). U osób $z$ choroba Hashimoto obserwuje się podwyższone stężenie w osoczu krwi przeciwciał z klasy IgG, skierowanych przeciw tyreoglobulinie (anty-TG) oraz tyreoperoksydazie (anty-TPO) (CATUREGLI i współaut. 2014). Niszczenie tyreoperoksydazy i tyreoglobuliny $\mathrm{w}$ wyniku autoagresji ogranicza i spowalnia proces jodowania reszt tyrozynowych i ogranicza lub uniemożliwia transport hormonów z koloidu do komórek pęcherzykowych. Skutkuje to zmniejszeniem ilości wydzielanych hormonów przez gruczoł tarczycowy i zwiększeniem wydzielania tyreoliberyny przez przysadkę, powodującego nadmierna stymulacja gruczołu tarczowego mogaca prowadzić do powstaniem wola (AJJAN i WeEtMan 2015). Szacuje się, że na niedoczynność tarczycy choruje około $2 \%$ osób. Odsetek ten rośnie wraz $z$ wiekiem i u osób powyżej 60 roku życia wynosi $5 \%$ i dotyczy głównie kobiet (MCLEOD i COOPER 2012). Do objawów klinicznych niedoczynności tarczycy można zaliczyć spowolnienie lipolizy i podstawowej przemiany materii, co objawia się nadmiernym gromadzeniem tkanki tłuszczowej i trudnościa $\mathrm{w}$ redukcji masy ciała. Spowolnione tętno i niskie ciśnienie krwi może objawiać się uczuciem zimna i niską jego tolerancja, suchościa i szorstkościa skóry. Często u pacjentów obserwuje się chrypę oraz uczucie ucisku spowodowane rozrostem gruczołu tarczowego, wypadanie włosów, a także obniżone libido, uczucie zmęczenia, trudności w koncentracji, wahania nastroju, osłabienie reakcji na bodźce, osłabienie siły mięśni i wydłużony czas ich relaksacji, a w konsekwencji zmniejszenie tolerancji wysiłku fizycznego. U osób $z$ autoimmunologicznym zapaleniem tarczycy może także występo- 
wać obrzęk skórny spowodowany nadmiernym gromadzeniem się wody, zmniejszenie kłębuszkowej filtracji nerek, zaburzenia oddychania, niedokrwistość i zaburzenia cyklu miesiączkowego kobiet (DILAS i współaut. 2011, CATUREGLi i współaut. 2014).

\section{DIETOTERAPIE W CHOROBACH AUTOIMMUNIZACYJNYCH}

Celiakia to choroba autoimmunologiczna, w przebiegu której dochodzi do niszczenia błony śluzowej jelita cienkiego. W jej rozwoju istotne znaczenie ma ekspozycja na białka glutenowe, w tym głownie prolaminy i gluteniny, oraz występowanie charakterystycznych dla tej choroby autoprzeciwciał: przeciw tkankowej transglutaminazie (anty-tTG), deaminowanym peptydom gliadyny (anty-DGP) i przeciw białkom cytoplazmy mięśni gładkich (anty-EMA), co prowadzi do rozwoju stanu zapalnego jelit. W konsekwencji dochodzi do postępującego przerostu krypt, zaniku kosmków jelitowych i w efekcie zespołu złego wchłaniania (LUDVIGSSON i współaut. 2014). Do objawów klinicznych celiakii zalicza się dyspepsję, wzdęcia, bóle brzucha, wodniste, tłuszczowe biegunki lub zaparcia, stany zapalne i nietolerancję dwucukrów. U osób dorosłych częściej niż u dzieci występuja również objawy pozajelitowe, takie ja: niedokrwistość $z$ niedoboru żelaza i/lub witaminy $\mathrm{B}_{12}$, osteopenia, osteoporoza, miopatie, objawy neurologiczne, bezpłodność, przedwczesna menopauza, zaburzenia płodności, częste infekcje, bóle głowy, obniżony nastrój i depresje. Wyróżnia się też skórną postać celiakii zwaną opryszczkowym zapaleniem skóry (łac. dermetitis herpetiformis) (GUJRAL i współaut. 2012). Wrażliwość na białka glutenowe $u$ osób $z$ celiakia jest zróżnicowana, ale u większości $z$ nich dzienne spożycie mniej niż $10 \mathrm{mg}$ glutenu nie prowadzi do nawrotu objawów (AKOBENG i THOMAS 2007). Ze względu na rodzaj i stopień nasilenia objawów, a także stan błony śluzowej jelit rozróżnia się postać klasyczna ( $z$ objawami $z$ przewodu pokarmowego), nieklasyczna (bez lub $z$ mało specyficznymi objawami $z$ przewodu pokarmowego) i potencjalna (bezobjawowa, ale ze stwierdzoną obecnością przeciwciał w osoczu krwi) (BAI i współaut. 2013). Na pełnoobjawowa, klasyczna postać celiakii choruje 0,1\% osób, z kolei na postać o nasilonych symptomach pozajelitowych od 0,3 do $1 \%$ populacji (SOCHA i CUKROWSKA 2012, NiCE 2015).

Głównym celem dietoterapii w chorobie Hashimoto jest ograniczenie spożycia składników żywności, które niekorzystnie wpływają na syntezę hormonów tarczycy oraz zwiększenie spożycia tych, które wykorzystywane sa do ich syntezy. Istotne jest także spowolnienie procesu chorobowego, przywrócenie stanu eutyrozy i zmniejszenie nasilenia objawów. Ważnym elementem postępowania dietetycznego jest również zmniejszenie stanu zapalnego w obrębie gruczołu tarczowego (ZAKRZEWSKA i współaut. 2015).

W związku $z$ częstym współistnieniem $Z$ autoimmunologicznym stanem zapalnym tarczycy nieprawidłowych reakcji na pokarm, w tym alergii i nietolerancji pokarmowych, $\mathrm{w}$ dietoterapii często stosuje się także dietę eliminacyjna oparta na wykluczeniu $z$ jadłospisu produktów zawierających $\mathrm{m}$. in. białka glutenowe i produkty mleczne, ze względu na silne właściwości antygenowe białek tych produktów. Przypuszcza się, że wyeliminowanie ich $z$ diety umożliwia u niektórych osób zmniejszenie nasilenia stanu zapalnego tarczycy (DENHAM i HILL 2013).

$Z$ diety osób $z$ celiakia należy wykluczyć produkty zawierajace $\mathrm{w}$ swoim składnie białka glutenowe pochodzace $z$ pszenicy, $\dot{z} y t a$, jęczmienia lub owsa o nieznanym pochodzeniu. Ze względu na często występujacca nietolerancję laktozy, szczególnie u osób z objawami ze strony przewodu pokarmowego, w celiakii często zalecana jest również jej czasowa lub stała eliminacja (SwORA i współaut. 2009).

Złożoność etiopatogenezy schorzeń autoimmunologicznych oraz brak skutecznych metod leczenia stanowi duże wyzwanie dla współczesnej nauki. W leczeniu daży się do stabilizacji stanu zdrowia pacjenta, stosujac leczenie objawowe, i utrzymania go jak najdłużej w fazie remisji choroby. Pozwala to na znaczną poprawę komfortu życia i zmniejszenie ryzyka powikłań. W ramach badań własnych podjęto próbę określenia wpływu na jakość życia i stan zdrowia diet eliminacyjnych zastosowanych przez osoby $z$ wybranymi schorzeniami autoimmunologicznymi, takimi jak choroba Hashimoto i celiakia. W badaniu tym wzięło udział 209 osób w wieku

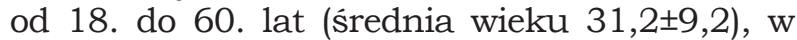
tym 81 kobiet chorych na chorobe Hashimoto oraz 106 kobiet i 12 mężczyzn chorych na celiakię. Dobór grupy był arbitralny, a kryterium wyłączenia było niestosowanie diety eliminacyjnej przez pacjenta oraz wiek poniżej 18. roku życia. Badania obejmowały retrospektywna ocenę jakości życia chorych przed $i$ po zastosowaniu diety eliminacyjnej oraz określenie wpływu profilu diet eliminacyjnych na stan zdrowia pacjentów. W badaniu wykorzystano, w zależności od rodzaju choroby, dwa kwestionariusze ankiet dotyczacych oceny jakości życia: Celiac Symptom Index (LEFFLER i współaut. 2009) i Thyroid-Related Patient-Reported Outcome 39 (SAWICKA-GUTAJ i współaut. 2015), a informacje zebrano wykorzystujacc metodę CAWI (ang. Computer 
Assisted Web Interviews). Każde pytanie było oceniane w skali czteropunktowej, przy czym mniejsza liczba punktów oznaczała lepsza samoocenę stanu zdrowia, w tym występowania objawów choroby i jakości życia. Kwestionariusz ankiety zawierał również pytania dotyczace masy ciała i wzrostu, na podstawie których obliczono wskaźnik masy ciała BMI (ang. body mass index). Stosujac analizę skupień $z$ wykorzystaniem modelu liniowego, osoby uczestniczace $\mathrm{w}$ badaniu podzielono na grupy różniące się w istotny sposób profilem diet eliminacyjnych i porównano wpływ profilu diety na jakość życia pacjentów. W celu analizy danych wykorzystano metody statystyczne: test t-studenta dla prób zależnych i dla prób niezależnych, sieci neuronowe Kohonena oraz test rozsądnej istotnej różnicy (RIR) Tukey'a, przyjmując poziom istotności $\mathrm{p} \leq 0,05$. Badania wykonano $w$ ramach projektu, na który uzyskano zgodę nr 36/2017 Komisji Etyki Badań Naukowych $z$ Udziałem Ludzi przy Wydziale Nauk o Żywieniu Człowieka i Konsupcji SGGW.

\section{SPECYFIKA DIET ELIMINACYJNYCH STOSOWANYCH PRZEZ OSOBY Z CHOROBAMI AUTOIMMUNOLOGICZNYMI}

Niedoczynność tarczycy wiąże się $z$ wyższym wskaźnikiem masy ciała i większą czę- stością występowania otyłości. Otyłość może być czynnikiem ryzyka autoimmunologicznego zapalenia tarczycy, a hormon tyreotropowy i hormony tarczycy moga uczestniczyć w różnicowaniu adipocytów i regulacji lipolizy (SANYAL I RAYCHAUDHURI 2016). Ponad połowa osób $z$ chorobami autoimmunologicznymi, uczestniczaca $\mathrm{w}$ badaniach miała prawidłową masę ciała, jednak średnia wartość BMI osób $z$ choroba Hashimoto była istotnie wyższa niż u osób $z$ celiakia $(24 \pm 5,5$ vs $\left.21,9 \pm 3,8 \mathrm{~kg} / \mathrm{m}^{2}\right)$. U $1 / 3$ osób chorych na chorobę Hashimoto występowała nadwaga, a u 20\% chorych na celiakię częściej obserwowano niedowage (Ryc. 1). Prawie wszystkie osoby $z$ choroba Hashimoto i niespełna połowa osób $z$ celiakia stosowała leki i/lub suplementy diety (Ryc. 2).

Wszystkie osoby $z$ celiakia deklarowały, że wyłączyły ze swojej diety także inne produkty, oprócz produktów glutenowych. Najwięcej osób wyeliminowało ze swojej diety laktozę i mleko krowie (Tabela 1). Wśród chorych na Hashimoto największy odsetek osób wskazał na eliminacje $z$ diety produktów $z$ pszenicy i zawierajacych laktozę $(2 / 3$ osób), mleka krowiego i produktów mlecznych (ponad połowa osób), soi oraz orzeszków ziemnych (Tabela 1).

Najczęstszym powodem dodatkowego eliminowania produktów spożywczych $z$ diety

Tabela 1. Produkty eliminowane $z$ racji pokarmowej przez osoby chore na celiakię i chorobę Hashimoto (\% odpowiedzi).

\begin{tabular}{|c|c|c|}
\hline $\begin{array}{l}\text { Wyeliminowana żywność i/lub } \\
\text { składnik żywnościowy }\end{array}$ & $\begin{array}{l}\text { Procent osób chorych na celiakię } \\
\qquad n=128\end{array}$ & $\begin{array}{l}\text { Procent osób chorych na chorobę Hashimoto } \\
\qquad \mathrm{n}=81\end{array}$ \\
\hline Zboża glutenowe & $99^{*}$ & $74^{*}$ \\
\hline Mleko krowie & $34^{*}$ & $69^{*}$ \\
\hline $\begin{array}{l}\text { Produkty mleczne (np. jogurt, } \\
\text { sery) }\end{array}$ & $20^{*}$ & $56^{*}$ \\
\hline Laktoza & $41^{*}$ & $73^{*}$ \\
\hline Jaja & 8 & 7 \\
\hline Mięsa i wędlin & 6 & 7 \\
\hline Ryby & 2 & 2 \\
\hline Skorupiaki i mięczaki & 7 & 11 \\
\hline Soja & $17^{*}$ & $69^{*}$ \\
\hline Orzeszki ziemne & $5^{*}$ & $33^{*}$ \\
\hline Orzechy inne & 12 & 10 \\
\hline Sezam & 5 & 5 \\
\hline Warzywa psiankowate & $5^{*}$ & $23^{*}$ \\
\hline Seler & 3 & 4 \\
\hline Inne produkty & 15 & 12 \\
\hline
\end{tabular}

* $p \leq 0,05 ;$ Test RIR Tukey’a 


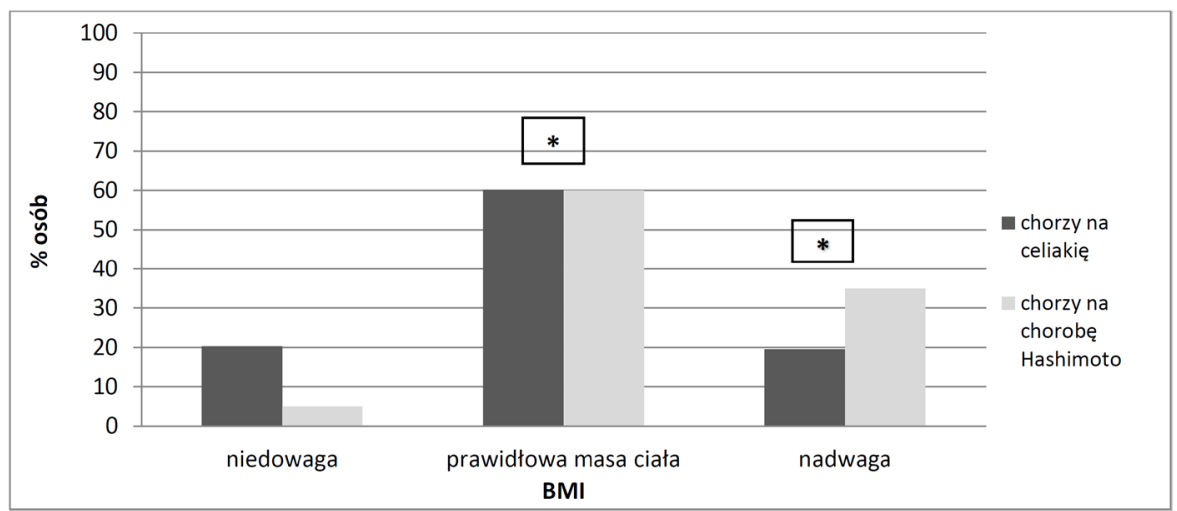

Ryc. 1. Rozkład wartości wskaźnika BMI u osób z celiakią i chorobą Hashimoto. ${ }^{*} p \leq 0,05$; Test Tukey’a

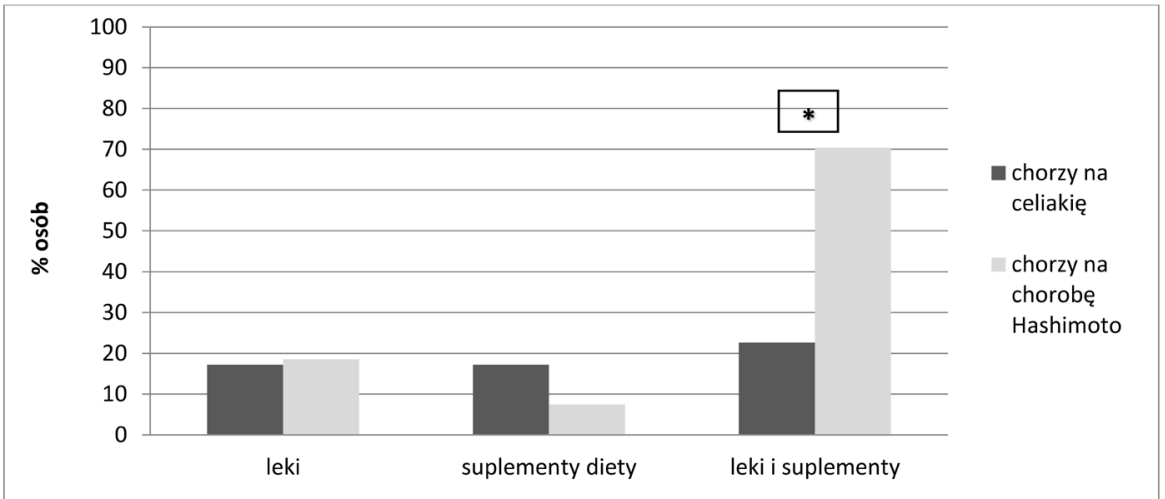

Ryc. 2. Udział osób z celiakią i choroba Hashimoto stosujaccych leki i/lub suplementy diety.

${ }^{*} p \leq 0,05$; Test RIR Tukey'a.

była stwierdzona nietolerancja pokarmowa. Wśród chorych na chorobę Hashimoto najczęstszym powodem stosowania diety eliminacyjnej była chęć poprawy stanu zdrowia (63\% osób), a jedynie $1 / 3$ osób eliminowała $z$ diety określone produkty opierajac się na zdiagnozowanej alergii i/lub nietolerancji pokarmowej.

Z grupy osób $Z$ celiakia wyłoniono trzy profile diet eliminacyjnych, w tym:

- osoby, które wyeliminowały $z$ diety głównie produkty glutenowe (grupa 1, n=84),

- osoby, które wyłączyły $z$ diety bezglutenowej także mleko krowie oraz produkty mleczne (grupa 2, $\mathrm{n}=15$ ),

- osoby, które wyłączyły z diety, oprócz produktów glutenowych, mleka krowiego i produktów mlecznych, także orzechy i soję (grupa 3, n=29).

Z grupy osób $z$ chorobą Hashimoto wyłoniono cztery profile diet eliminacyjnych, w tym: $\mathrm{n}=13$ )

produkty glutenowe i soję (grupa 1,

- mleko, produkty mleczne i soję (grupa $2, \mathrm{n}=22$
- produkty glutenowe, mleko i produkty mleczne oraz soję (grupa $3, n=31$ )

- produkty glutenowe, produkty mleczne i mleko krowie, soję, orzeszki ziemne i warzywa psiankowate (grupa 4, n=15).

\section{WPEYW DIET ELIMINACYJNYCH NA JAKOSC ZYCIA OSOB Z CHORAMI AUTOIMMUNOLOGICZNYMI}

\section{CELIAKIA}

Po zastosowaniu diety eliminacyjnej $u$ 96\% osób z celiakia zaobserwowano zmniejszenie nasilenia większości objawów, średnio o 1 punkt w 4. punktowej skali. Największa poprawę stwierdzono w przypadku występowania biegunek - czestość ich wystepowania u pacjentów zmniejszyła się średnio o 58\%. Najbardziej dokuczliwym objawem przed zastosowaniem diety eliminacyjnej było uczucie wzdętego brzucha i niski poziom "siły i energii życiowej", a nasilenie obu objawów po zastosowaniu dietoterpii zmniejszyło się o około 50\% (Ryc. 3).

U osób eliminujących produkty glutenowe, mleko i soję oraz orzechy (grupa 3) 


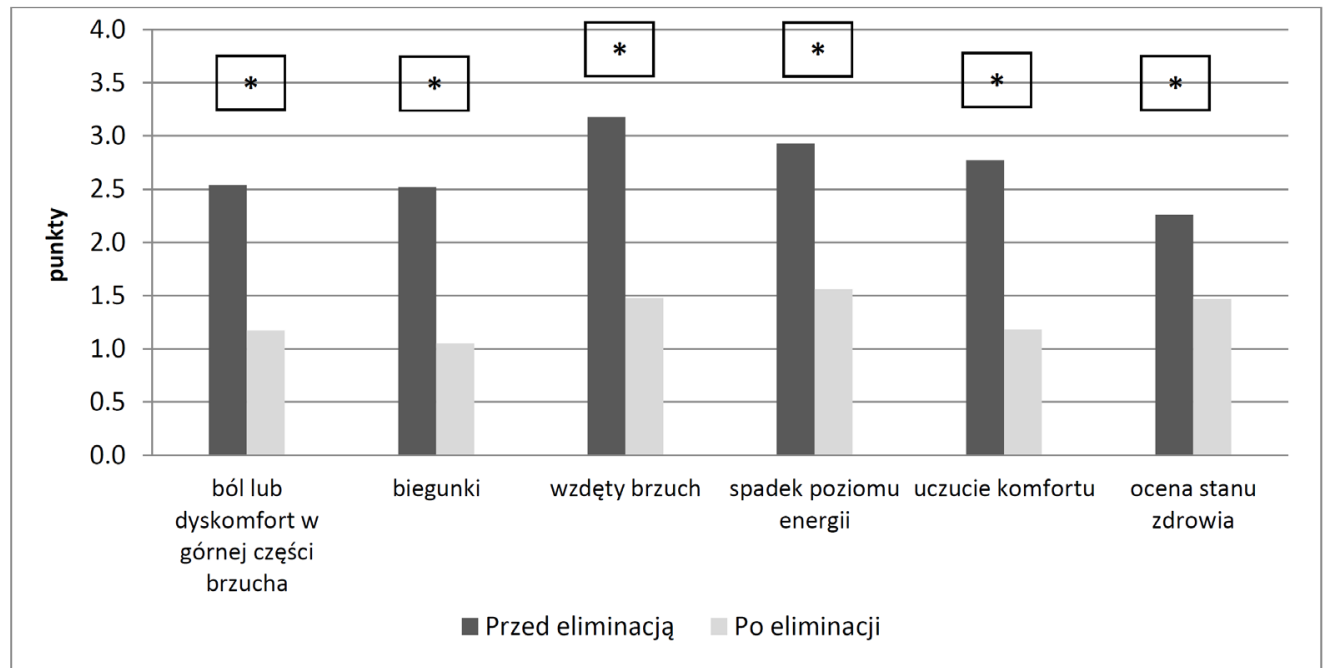

Ryc. 3. Nasilenie wybranych objawów u osób chorych na celiakię przed i po zastosowaniu diety eliminacyjnej.

${ }^{*} p \leq 0,05$; test $t$-Studenta dla prób zależnych; skala od 0 do 4 ; 0 - nigdy, 4 - zawsze

zaobserwowano poprawę stanu zdrowia $\mathrm{u}$ wszystkich badanych, a nasilenie objawów zmniejszyło się średnio o 54\%. Respondenci deklarowali, że przed zastosowaniem diety eliminacyjnej odczuwane objawy występowały często, natomiast po zastosowaniu diety eliminacyjnej dolegliwości występowały rzadko. Największa zmiana dotyczyła zwiększenia uczucia komfortu/spokoju oraz zmniejszenia wzdęć brzucha - średnio o 66\%. U osób w tej grupie zmniejszyła się również częstość występowania bólu, w tym bólu głowy lub dyskomfortu w jamie brzusznej, zmiana ta była większa o $15 \%$ w odniesieniu do osób, które wyeliminowały jedynie gluten i produkty mleczne (grupa 2). Podobnie częstość występowania nudności oraz uczucia niepełnego wypróżnienia zmniejszyła się w największym stopniu u osób eliminujących oprócz zbóż glutenowych także mleko, przetwory mleczne, soję i orzechy (grupa 3), a najmniejsze zmiany zaobserwowano u osób, które wyeliminowały tylko gluten (grupa 1). Częstość występowania tych objawów była mniejsza o około 50\% niż u osób z celiakią eliminujaccych wyłącznie zboża glutenowe oraz gluten i produkty mleczne (Ryc. 4).

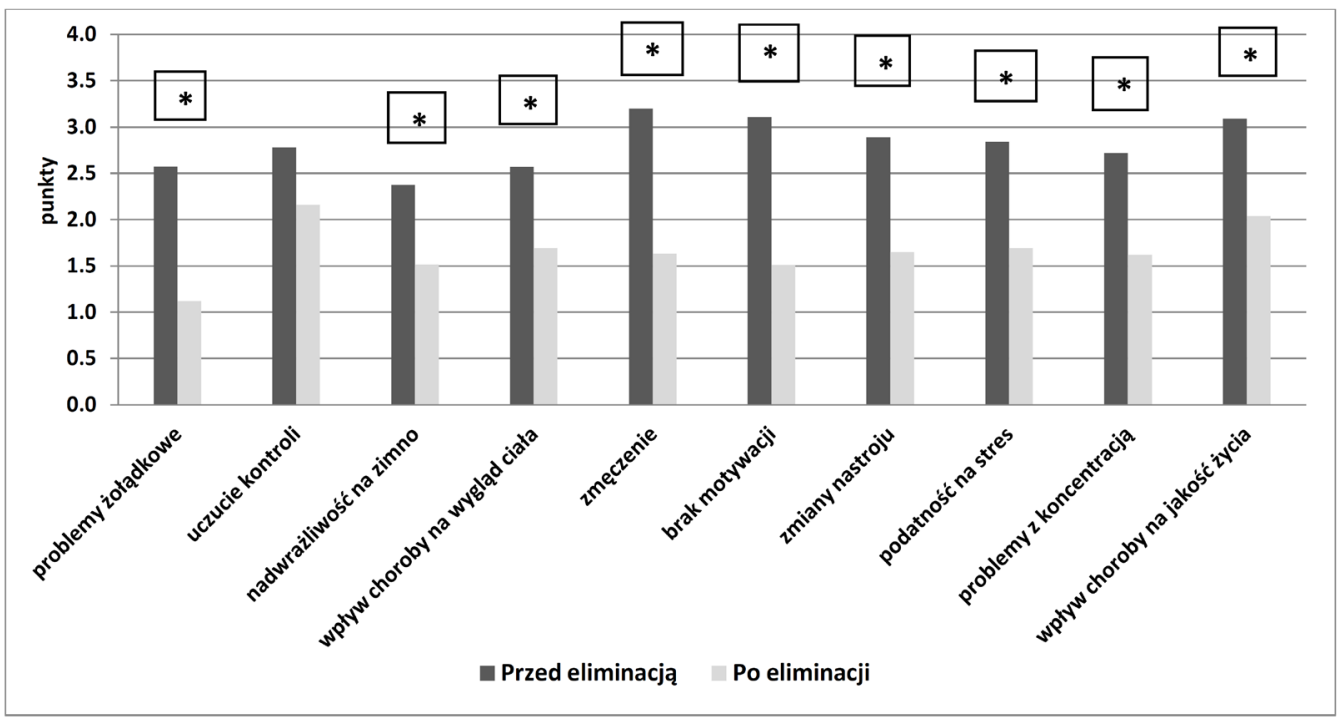

Ryc. 4. Zmiana nasilenia wybranych objawów u osób $z$ celiakią w zależności od profilu diety eliminacyjnej. 
Częstość występowania uczucia spokoju i komfortu zwiększyła się najbardziej u osób eliminujących $z$ diety nie tylko gluten, ale i orzechy, mleko i produkty mleczne oraz soję. U tych osób nasilenie uczucia komfortu zwiększyło się dużo bardziej niż u osób na diecie wyłącznie bezglutenowej i u osób będących na diecie bezglutenowej i bezmlecznej (Ryc. 4). Poprawa stanu zdrowia u osób chorych na celiakię, będących na diecie eliminującej orzechy, może być zwiąana z reakcja krzyżową pomiędzy przeciwciałami przeciw gliadynie a odpowiednimi antygenami. VOJDANI i TARASH (2013) w warunkach in vitro nie zaobserwowali by występujace $u$ osób $z$ celiakia przeciwciała przeciw a-gliadynie reagowały krzyżowo $z$ antygenami jaj. Nie można jednak wykluczyć, że poprawa stanu zdrowia u osób eliminujących orzechy była spowodowana dodatkowymi reakcjami alergicznymi współistniejącymi $z$ chorobami autoimmunologicznymi (DENHAM i HiLl 2013). Reakcje krzyżowe moga nasilać stan zapalny $\mathrm{w}$ narzadach objętych procesami autoimmunologicznymi, a obecność reaktywnych limfocytôw $\mathrm{T}$ może sprzyjać rozpoznawaniu własnych białek jako obce. Przykładowo, białko pochodzace $z$ pszenicy lub bobu może reagować krzyżowo $\mathrm{z}$ ludzkim antygenem IA2 i prowadzić do nasilenia stanu zapalnego i autoagresji przeciwko komórkom $\beta$ trzustki (HONEYMAN i współaut. 1998). Stan zapalny $w$ narzadach objętych procesem autoagresji moga nasilać również alergie IgE-zależne, powodujac uszkodzenia narzadowe i zaostrzajacc przebieg choroby (Mikoś i współaut. 2014). Autoantygeny, które reaguja krzyżowo $z$ egzogennymi alergenami, moga utrzymać lub nawet zwiększyć alergiczna odpowiedź immunologiczna na ten alergen. Ponadto, stężenie autoreaktywnych IgE we krwi wzrasta u osób narażanych na ciagły kontakt $z$ alergenami oraz u osób $z$ chorobami autoimmunologicznymi nie leczących się $z$ powodu alergii (VALENTA i współaut. 2008, CHINTHRAJAH i współaut. 2016). W przypadku chorób autoimmunologicznych nasilenie stanu zapalnego wiaże się $z$ niszczeniem tkanek objętych procesami autoagresji oraz gorszym i bardziej burzliwym przebiegiem choroby (GAEECKA i SzACHTA 2013).

$U$ osób chorych na celiakię $z$ powodu uszkodzenia kosmków jelitowych często obserwuje się wtórna nietolerancję laktozy (GiEzowska i GiEzowski 2014). W badaniu własnym $1 / 3$ osób stosowała dietę bezmleczną. KRISTJÁNSSON i współaut. (2007) zaobserwowali, że u osób chorych na celiakię spożycie białka mleka krowiego, głównie kazeiny, w 50\% przypadków wywołało silna reakcję zapalną w błonie śluzowej jelita, po- dobna do tej, która powstaje $\mathrm{w}$ przypadku spożywania glutenu. Badacze stwierdzili, że u niektórych osób spożywanie mleka krowiego może być odpowiedzialne za uporczywe utrzymywanie się objawów chorobowych, pomimo stosowania diety bezglutenowej. Natomiast VOJDANI i TARASH (2013) stwierdzili, że przeciwciała przeciw a-gliadynie silnie reaguja krzyżowo $z$ kazeina i moga nasilić stan zapalny w błonie śluzowej jelit. W badaniu własnym u osób będacych na diecie bezglutenowej i bezmlecznej nie stwierdzono jednak istotnie większej poprawy stanu zdrowia niż u osób będących wyłącznie na diecie bezglutenowej. Wydaje się więc, że eliminacja mleka nie była czynnikiem wpływajacym na stan zdrowia $w$ tej grupie pacjentów $z$ choroba trzewna.

\section{CHOROBA HASHIMOTO}

Główną metodą leczenia choroby Hashimoto jest, oprócz farmakoterapii, ograniczenie spożycia składników żywności, które niekorzystnie wpływaja na syntezę hormonów tarczycy, oraz zwiększenie spożycia tych, które wykorzystywane sa do ich syntezy (m. in. jodu, selenu, witaminy D) (DUNTAS 2015, CHAUDHARY i współaut. 2016, WichMAN i współaut. 2016). Ważnym elementem postępowania dietetycznego jest również zmniejszenie nasilenia stanu zapalnego gruczołu tarczowego i eliminacja alergenów pokarmowych, które moga być $z$ tym stanem związane. Często eliminowanymi produktami spożywczymi sa produkty zawierajace białka glutenowe oraz produkty mleczne, m.in. ze względu na ich silne właściwości antygenowe (ZAKRZEWSKA i współaut. 2015). W badaniu własnym stwierdzono, że u osób $z$ choroba Hashimoto zastosowanie diety eliminacyjnej zmniejszyło średnio o 38\% stopień nasilenia objawów. Przed zastosowaniem diety eliminacyjnej stopień nasilenia objawów był umiarkowany, jednak po jej zastosowaniu osoby uczestniczace $\mathrm{w}$ badaniu deklarowały, że dolegliwości te odczuwaja rzadko. Największa poprawe stwierdzono w przypadku objawów żołądkowych (średnio o 56\%), a najmniejsza zmiana dotyczyła uczucia samokontroli (średnio o 22\%). WATT i współaut. (2014) ocenili za pomoca kwestionariusza Thypro jakość życia 84 osób chorych na chorobe Hashimoto przed rozpoczęciem leczenia lewotyroksyna, a następnie 6 miesięcy po rozpoczęciu farmakoterapii. Terapia poprawiła stan zdrowia pacjentów z choroba Hashimoto, jednak zmiana w odczuwaniu objawów była mała, co badacze tłumaczyli tym, że odczuwane objawy przed rozpoczęciem badania mialy stosunkowo niski stopień nasilenia. 
W badaniu własnym po zastosowaniu diety eliminacyjnej aż 12 osób $z$ choroba Hashimoto wskazało, że uczucie samokontroli uległo pogorszeniu. Dieta eliminacyjna zmniejszyła jednak częstość występowania nadwrażliwości na zimno, która przed zastosowaniem diety występowała dosyć często, a po jej zastosowaniu czasami - poprawa ta wynosiła 36\%. Przed zastosowaniem diety eliminacyjnej pacjenci $z$ choroba Hashimoto ocenili, że choroba dosyć mocno wpłynęła na ich wygląd fizyczny, po zastosowaniu diety eliminacyjnej uznali, że choroba ma umiarkowany wpływ na wyglad ich ciała. WATT i współaut. (2014) zaobserwowali, że wprowadzenie terapii hormonalnej w największym stopniu zmieniło odczuwanie dolegliwości zwiazanych ze zmęczeniem (poziom energii, brak siły i motywacja, uczucie wypalenia). Podobnie, osoby uczestniczace w badaniu własnym intensywnie odczuwały powyższe objawy, natomiast po 6 miesiacach stosowania diety ich nasilenie określały jako średnie. Znaczaca zmiana dotyczyła szczególnie występowania zmęczenia i braku motywacji do działania. Przed zastosowaniem diety eliminacyjnej pacjenci deklarowali, że brak motywacji i zmęczenie występowały często i były dość mocno dokuczliwe, natomiast po zastosowaniu diety eliminacyjnej objawy te występowały czasami lub rzadko. Zastosowana dieta eliminacyjna wpłynęła również na stabilizację nastroju badanych osób, który przed zastosowaniem dietoterapii był wyraźnie zmienny, natomiast po jej zastosowaniu pacjenci $z$ Hashimoto ocenili, że ich nastrój tylko czasami był zmienny. Poziom energii $u$ osób chorych na chorobę Hashimoto zwiększył się o 27\% (Ryc. 5). Podobnie, przed zastosowaniem diety eliminacyjnej zaburzenia procesów poznawczych i podatność na stres u osób $z$ choroba Hashimoto były silnie dokuczliwe, a po zastosowaniu diety objawy stały się mniej dokuczliwe. Problemy $z$ koncentracja, podatność na stres i problemy $z$ zapamiętywaniem, występowały rzadziej średnio o 40\%. Dieta eliminacyjna korzystnie wpłynęła na subiektywna ocenę jakości życia przez osoby $z$ choroba Hashimoto. Przed zastosowaniem diety eliminacyjnej pacjenci deklarowali, że choroba tarczycy ma duży wpływ na jakość ich życia, natomiast po zastosowaniu diety osoby te przyznały, że choroba ma umiarkowany wpływ na jakość ich życia (Ryc. 5).

Wśród osób chorych na chorobę Hashimoto największa poprawe stanu zdrowia zaobserwowano wśród tych, które wyłączyły $z$ diety produkty glutenowe i mleczne, soję, warzywa psiankowate i orzeszki ziemne. Najmniejsza poprawę $\mathrm{w}$ odniesieniu do pozostałych osób zaobserwowano w przypadku tych, które wyłączyły $z$ diety mleko krowie i produkty mleczne.

U 92\% osób stosujacych dietę bezglutenowa i eliminujacych soję (grupa 1) zaobserwowano zmniejszenie odczuwania dolegliwości, ale zaobserwowana poprawa stanu zdrowia była umiarkowana. Odczuwane dolegliwości przed zastosowaniem diety eliminacyjnej występowały czasami, natomiast po zastosowaniu diety dolegliwości występowały rzadko. U osób $z$ chorobą Hashimoto stosujacych dietę bezmleczną i eliminujacych soję (grupa 2), stan zdrowia poprawił się istotnie również u 90\% chorych, jednak poprawa ta była mała, występujaca, tylko w przypadku niektórych objawów, chociaż u pacjentów $z$

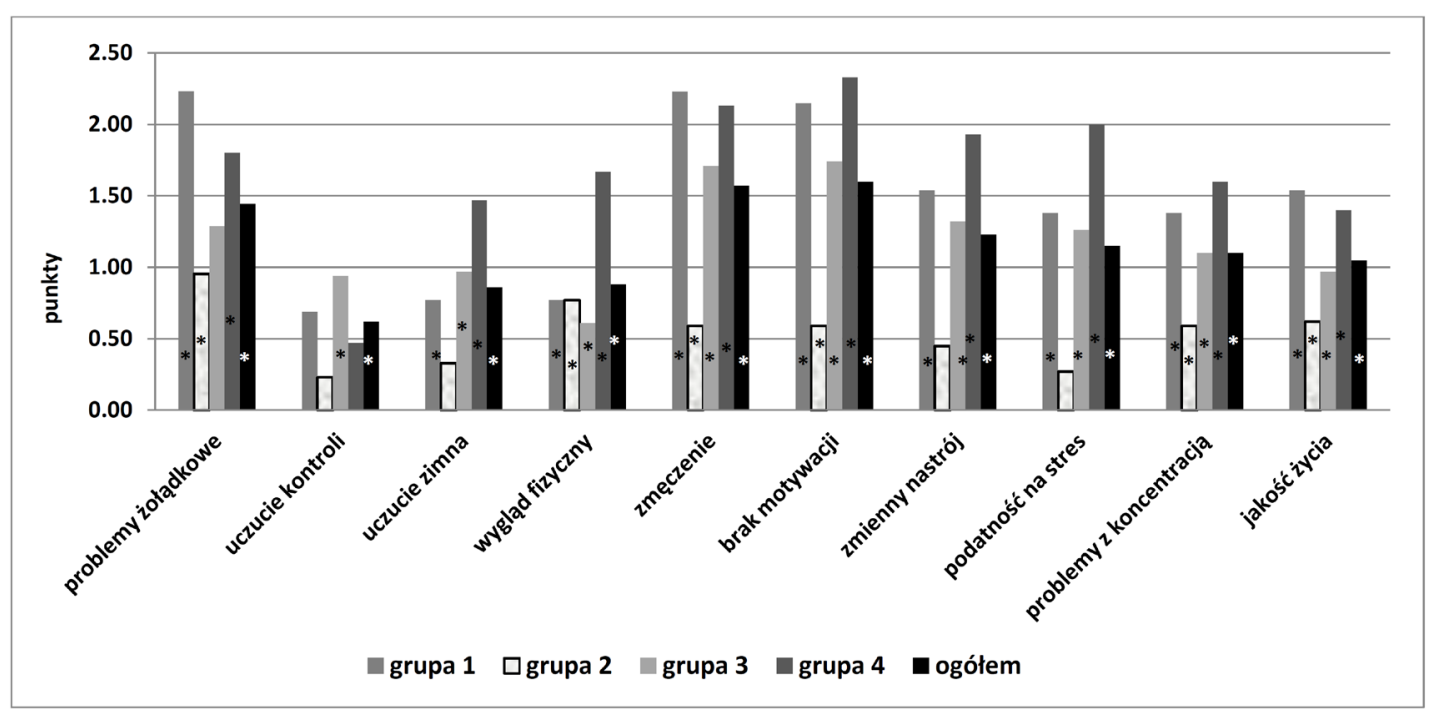

Ryc. 5. Nasilenie dolegliwości u osób chorych na Hashimoto przed i po zastosowaniu diety eliminacyjnej.

${ }^{*} p \leq 0,05$; test $t$-Studenta dla prób zależnych; skala od 0 do $4 ; 0$ - wcale, 4 - bardzo mocno; 
Hashimoto często występuje nietolerancja laktozy (ZAKRZEWSKA i współaut. 2015). Poprawa w odczuwaniu wszystkich dolegliwości u osób pozostających na diecie bezmlecznej była trzykrotnie mniejsza niż u osób eliminujących gluten, orzechy, soję, mleko krowie i produkty mleczne. AsIK i współaut. (2014), badajac osoby $z$ choroba Hashimoto wykazali, że zastosowanie diety bezmlecznej u większości chorych $z$ nietolerancja laktozy przyczynić się mogło do zmniejszenia stężenia TSH we krwi, co mimo braku zmiany stężenia fT4, pozwoliło zmniejszyć dawkę lewotyroksyny. Takich zmian nie zaobserwowano u osób bez nietolerancji laktozy. W badaniu własnym nie zaobserwowano jednak tak widocznych efektów diety bezlaktozowej, mimo że nietolerancja laktozy została zdiagnozowana u ponad połowy osób, które eliminowały mleko, produkty mleczne i soję.

U ponad $90 \%$ osób $z$ choroba Hashimoto stosujących dietę bezglutenowa, bezmleczna i eliminujacych soję (grupa 3) zaobserwowano umiarkowana poprawę stanu zdrowia, ale większą niż u osób stosujących dietę bezmleczną i eliminujacych soję (grupa 2). U osób eliminujących głównie gluten i soję zaobserwowano największa poprawę w odczuwaniu dolegliwości żołądkowych.

Największą zmianę w odczuwaniu objawów zaobserwowano u osób o profilu eliminacyjnym bazujaccym na wykluczeniu $Z$ diety glutenu, mleka krowiego i produktów mlecznych, soi, orzechów i warzyw psiankowatych (grupa 4). Poprawa stanu zdrowia u osób stosujących dietę eliminacyjna o tym profilu była bardzo duża, a dolegliwości odczuwane jako dość silnie przed wprowadzeniem diety, po jej zastosowaniu miały niski stopień nasilenia. U osób eliminujących gluten, orzechy, soję, mleko krowie i produkty mleczne zmniejszyło się znacząco odczucie nadwrażliwości na zimno - zmiana ta była o 70\% większa niż u osób eliminujących produkty glutenowe i soję (Ryc. 6). Poprawa w odczuwaniu zmęczenia i braku motywacji do działania była bardzo duża zarówno u osób eliminujących jedynie zboża glutenowe i soję, jak i u osób eliminujących dodatkowo orzechy, produkty mleczne i warzywa psiankowate. Zmiana w odczuwaniu powyższych dolegliwości u osób $z$ grupy 1 i 4 była ponadtrzykrotnie większa niż u osób eliminujacych produkty mleczne i soję. Podobnie, nastrój ustabilizował się najbardziej u osób eliminujących gluten, orzechy, soję, mleko krowie i produkty mleczne i były to zmiany prawie o połowę większe niż u osób eliminujacych $z$ diety gluten, soję i produkty mleczne. Podatność na stres najbardziej zmieniła się u osób eliminujących, oprócz zbóż glutenowych, produktów mlecznych i soi, również orzechy, a poprawa ta była aż o $74 \%$ większa niż u wszystkich pozostałych osób. Odczuwanie problemów z koncentracja oraz wpływ choroby na wygląd ciała również najbardziej zmienił się u osób eliminujących gluten, orzechy, soję, mleko krowie i produkty mleczne i warzywa psiankowate, a zmiana ta była ponaddwukrotnie większa niż u pozostałych osób. Znamienna poprawę jakości życia wskazały jednak zarówno osoby eliminujace gluten, orzechy, soje, mleko krowie i produkty mleczne, jak i osoby eliminujace $z$ diety gluten i soję (Ryc. 6).

U osób $z$ chorobą Hashimoto obserwuje się częstsze występowanie celiakii niż u osób zdrowych (SPADACCINO i współaut. 2008, MIŚKIEWICZ i współaut. 2012, SHARMA i współaut. 2016, FREEMAN 2016). Obydwa schorzenia zwiazane sa $z$ podobna predyspozycją genetyczna związana $z$ genami układu HLA klasy II, w tym HLA-DQ2 i $H L A-D Q 8$, kodujacymi czasteczki prezentujace antygeny, oraz $z$ polimorfizmami pojedynczych nukleotydów w rejonach genów kodujacych

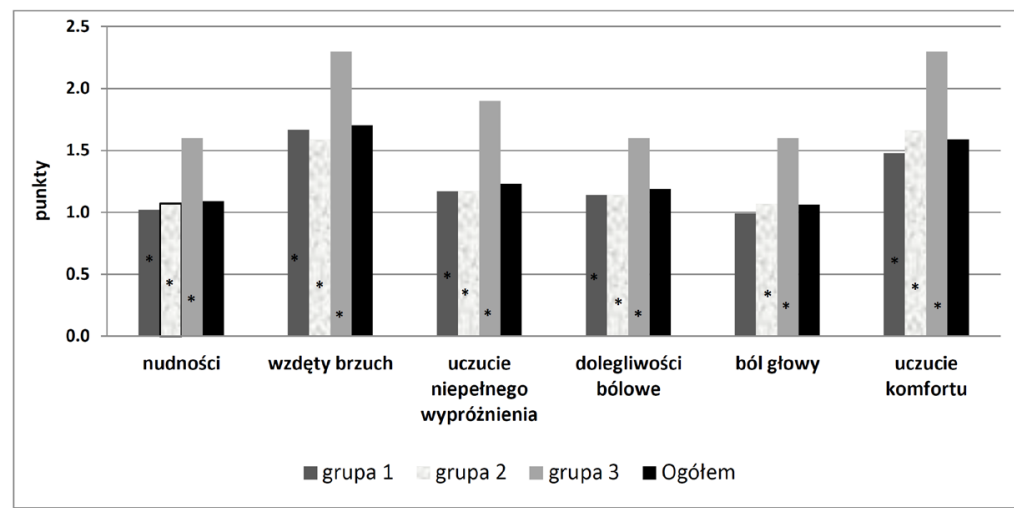

Ryc. 6. Zmiany w odczuwaniu objawów u osób chorych na chorobę Hashimoto w zależności od zastosowanego profilu diety eliminacyjnej

${ }^{*} p \leq 0,05$; test $t$-Studenta dla prób zależnych; skala punktowa od -4 do 4 ; wyższy wynik to większa poprawa. 
czynniki prozapalne, $\mathrm{w}$ tym cytokiny IL18 i INF- $\gamma$ (MORMILE 2016). Autoprzeciwciała przeciwko transglutaminazie tkankowej mogą mieć znaczenie w rozwoju dysfunkcji gruczołu tarczowego, prawdopodobnie przez ich reakcję $z$ transglutaminaza obecna w tkance tarczycy i rozwoju stanu zapalnego (DUNTAS 2009). Badania CARROCCIO i współaut. (2015) pokazują, że podobnie jak chorzy na celiakię, pacjenci $z$ nieceliakalna nadwrażliwością na gluten częściej choruja na choroby o podłożu autoimmunizacyjnym. Przypuszcza się, że gluten może wpływać na przepuszczalność bariery jelitowej, prowadząc do zwiększenia ekspozycji na antygeny, a podobieństwo białek zbóż glutenowych do autoantygenów może zapoczątkować proces autoimmunizacyjny. Aktywacja reakcji immunologicznych zależnych od limfocytów T i wyzwalanie produkcji autoprzeciwciał reagujacych może sprzyjać aktywacji układu immunologicznego $\mathrm{w}$ kierunku reakcji prozapalnych (DIAMANTI i współaut. 2016).

Nie można wykluczyć, że część osób $z$ choroba Hashimoto uczestniczacych w badaniu własnym miała również niezdiagnozowana celiakię, a przez to dieta bezglutenowa mogła mieć większy wpływ na poprawę ich stanu zdrowia (ZAKRZEWSKA i współaut. 2015). We włoskim badaniu SATEGNA-GUIDETTI i współaut. (2001) z udziałem osób chorych na celiakię $z$ współtowarzysząca niedoczynnościa tarczycy zaobserwowano, że ścisłe stosowanie diety bezglutenowej trwajace rok poprawiło parametry funkcji tarczycy, w tym stężenie TSH, fT3, fT4, i zmniejszyło poziom anty-TPO we krwi, a u części $z$ tych pacjentów aktywna postać choroby zmieniła się w postać subkliniczną.

Podobnie w badaniu Cosnes i współaut. (2008), które objęło 924 pacjentów $z$ celiakia, w tym 19\% chorych $z$ przynajmniej jedna inna choroba autoimmunologiczna stwierdzono, że dieta bezglutenowa może korzystnie wpływać na rozwój uogólnionej autoimmunizacji. Autorzy wykazali, że ryzyko pojawienia się chorób autoimmunologicznych u pacjentów stosujacych dietę bezglutenowa było około dwukrotnie mniejsze niż u osób, które jej nie stosowały. Jednak DIAMANTI i współaut. (2011) nie wykazali wpływu dwuletniej eliminacji białek glutenowych $\mathrm{z}$ diety na obniżenie występowania autoimmunologicznego zapalenia tarczycy $u$ dzieci $z$ celiakia, a retrospektywne badania CASSIO i współaut. (2010) pokazały dwukrotne zwiększenie jego występowania po 14. latach stosowania diety bezglutenowej u dzieci $z$ celiakią. Metso i współaut. (2012) zaobserwowali częstsze występowanie choroby Hashimoto $u$ osób $z$ nowo zdiagnozowana celiakia, jednak po roku stosowania diety bezglutenowej ry- zyko pojawienia się $u$ nich autoimmunologicznego zapalenia tarczycy nadal było większe, w porównaniu do odpowiedniej grupy osób zdrowych. Brak jest także dowodów na skuteczność stosowania diet eliminacyjnych, w tym eliminacji białek glutenowych czy białek mleka krowiego, u osób $z$ ta choroba tarczycy nie wykazujacych cech celiakii $\mathrm{i} /$ lub alergii. W badaniu własnym u osób chorych na chorobę Hashimoto zastosowanie diety eliminacyjnej zwiazane było $z$ umiarkowana, subiektywna poprawa stanu zdrowia. W największym stopniu do poprawy stanu zdrowia u osób $z$ chorobą Hashimoto przyczynił się profil diety eliminacyjnej oparty na wyłączeniu $z$ niej nie tylko produktów glutenowych i soi, ale także mleka krowiego, produktów mlecznych, warzyw psiankowatych i orzeszków ziemnych. Zmiana w odczuwaniu objawów u osób stosujących tego typu dietę eliminacyjna była bardzo duża.

Według Grupy Ekspertów Sekcji Dietetyki Medycznej Polskiego Towarzystwa Żywienia Pozajelitowego, Dojelitowego i Metabolizmu (POLSPEN) (SZOSTAK-WEGIEREK i współaut. 2018), stosowanie rygorystycznej diety bezglutenowej $u$ pacjentów $z$ choroba Hashimoto jest uzasadnione jedynie w przypadku współistnienia celiakii, a stosowanie diety bezglutenowej powinno być poprzedzone wykonaniem serologicznych badań przesiewowych w kierunku celiakii czy alergii. Nie można jednak wykluczyć, że u części chorych na chorobę Hashimoto może współwystępować nieceliakalna, niealergiczna nadwrażliwość na gluten, co może uzasadniać wprowadzenie u nich diety eliminacyjnej. Należy dodać, że ewentualne korzystne działanie diety bezglutenowej na przebieg choroby Hashimoto u tych chorych wymaga dalszych badań (TONUTTI i BizzARO 2014, RoY i współaut. 2016). Możliwa jest również większa predyspozycja osób $z$ chorobami autoimmunologicznymi do występowania innych niepożądanych reakcji pokarmowych zwiazanych $z$ nadpobudliwa, nieprawidłowa odpowiedzia na inne niż białka składniki żywności [np. aminy wazoaktywne, krótkołańcuchowe węglowodany, wolniej absorbowane $z$ przewodu pokarmowego: FODMAP (zbiór krótkołańcuchowych cukrów), salicylany, fruktany, aglutyninę czy lektyny]. Zwiazek tych zaburzeń może wynikać ze zwiększonej immunoreaktywności obserwowanej u osób $z$ celiakią i chorobac Hashimoto lub działaniem na tkanki docelowe zwiazanych $z$ tymi schorzeniami autoantygentow (NAIYER i współaut. 2008, BOELAERT i współaut. 2010, LUNDIN I WIJMENGA 2015).

Nie ma dowodów wskazujących na znaczenie stosowania diet eliminacyjnych, w tym diety bezglutenowej, w zapobieganiu 
chorobom autoimmunizacyjnym. Jest jednak wysoce prawdopodobne, że tego typu modyfikacje dietetyczne moga mieć istotne znaczenie we wspomaganiu leczenia niektórych chorób autoimmunologicznych, zmniejszając progresję i występowanie powikłań, szczególnie u osób z choroba Hashimoto. Długotrwałe stosowanie diet eliminacyjnych niesie jednak za sobą ryzyko niedoborów pokarmowych i wymaga stałej kontroli oraz wsparcia poradnictwa żywieniowo-dietetycznego (Collin 2005). Wieloletnie stosowanie diety bezglutenowej, w przypadku złego jej zbilansowania, niesie ze soba ryzyko wielu niekorzystnych skutków zdrowotnych, w tym także zwiększenie ryzyka występowania zespołu metabolicznego i chorób układu krażenia (LUDVIGSSON i współaut. 2012, DE MARCHI i współaut. 2013, NEWNHAM i współaut. 2016).

\section{PODSUMOWANIE}

Diety eliminacyjne moga odgrywać istotna rolę we wspomaganiu leczenia niektórych chorób autoimmunologicznych. U osób chorych na celiakię zaobserwowano, że istotne znaczenie, oprócz wyłączenia $z$ diety glutenu, miała również eliminacja jaj i orzechów. Dodatkowa eliminacja laktozy, mleka krowiego i produktów mlecznych nie przyczyniła się jednak do ogólnej poprawy stanu zdrowia pacjentów $z$ celiakią.

$\mathrm{U}$ osób chorych na chorobę Hashimoto zastosowanie diety eliminacyjnej zwiazane było $z$ umiarkowana poprawa stanu zdrowia. W największym stopniu do poprawy stanu zdrowia i zmniejszenia nasilenia objawów u chorych przyczynił się jednak profil diety oparty na eliminacji glutenu, orzechów, soi, mleka krowiego i produktów mlecznych. Najmniejsza poprawę stanu zdrowia zaobserwowano u osób eliminujacych $z$ diety laktozę i soję. Dieta bezmleczna nie wpłynęła na poprawę stanu zdrowia u osób chorych na chorobe Hashimoto.

\section{Streszczenie}

Złożoność etiopatogenezy schorzeń autoimmunologicznych, w tym celiakii i choroby Hashimoto, oraz brak skutecznej farmakoterapii powoduje, że istotnym czynnikiem poprawy stanu zdrowia i komfortu życia oraz zmniejszenia rozwoju powikłań może być odpowiednia dietoterapia. W tym celu przeprowadzono retrospektywne badania ankietowe. Wzięło w nich udział 209 osób w wieku od 18. lat do 60. lat,w tym 81 kobiet chorych na chorobę Hashimoto oraz 106 kobiet i 12 mężczyzn chorych na celiakię. Opracowane statystycznie ich wyniki pokazały, że jedna trzecia osób $z$ celiakia, oprócz wyłaczenia zbóż glutenowych, eliminowała $z$ diety produkty mleczne. Większość osób z choroba Hashimoto wyłaczyła $z$ diety zboża glutenowe, a ponad połowa również produkty mleczne i soję. Największa poprawę stanu zdrowia, w tym szczególnie zmniejszenie występowania nudności, wzdęć, dolegliwości bólowych oraz zwiększenie uczucia komfortu obserwowały osoby $z$ celiakia eliminujące oprócz zbóż glutenowych: mleko i jego przetwory, orzechy i soję. Podobnie, największe zmiany samopoczucia zwiazanego $z$ objawami choroby Hashimoto, w tym szczególnie zmniejszenie nadwrażliwości na temperature, uczucia suchości skóry oraz poprawę samopoczucia, deklarowały osoby eliminujące zboża glutenowe, produkty mleczne, orzechy arachidowe i warzywa psiankowate. Leczenie celiakii oparte na diecie bezglutenowej, połaczone z eliminacją orzechów i soi, może przynieść największe korzyści zwiazane $z$ poprawa stanu zdrowia i jakości życia, a eliminacja zbóż glutenowych i orzeszków ziemnych może wspomagać poprawę jakości życia osób $z$ choroba Hashimoto.

\section{LITERATURA}

AJJan R. A., WeEtman A. P., 2015. The Pathogenesis of Hashimoto's Thyroiditis: Further Developments in our Understanding. Horm. Metab. Res. 47, 702-710.

AKobeng A. K., Thomas A. G., 2007. Systematic review: tolerable amount of gluten for people with coeliac disease. Aliment. Pharmacol. Ther. 27, 1044-1052.

Asik M., Gunes F., Binnetoglu E., Eroglu M., BOZKuRT N., SEN H., AKBAL E., BAKAR C., BEYAZIT Y., UKINC K., 2014. Decrease in TSH levels after lactose restriction in Hashimoto's thyroiditis patients with lactose intolerance. Endocrine 46, 279-284.

BAi J. C., Fried M., Corazza G. R., Schuppan D., FARTHING M., CATASSI C., GRECO L., COHEN $\mathrm{H}$, CiacCI C, EliakiM R, FASANO A, GONZÁleZ A, KRABSHUIS JH, LEMAIR A, WORLD GASTROENTEROLOGY ORGANIZATION, 2013. World Gastroenterology Organization global guidelines on celiac disease. J. Clin. Gastroenterol. 47, $121-126$

Boelaert K., Newby P. R., Simmonds M. J., HOLDER R. L., CARR-SMITH J. D., HEWARD J. M., Manji N., Allahabadia A., ARmitage M., ChatTerJee K. V., Lazarus J. H., Pearce S. H., VAIDYA B., GOUGH S. C., FRANKLYN J. A, 2010. Prevalence and relative risk of other autoimmune diseases in subjects with autoim mune thyroid disease. Am. J. Med. 123, 183. e1-183.e9.

CARRoccio A., D'Alcamo A., Cavataio F., Soresi M., Seidita A., Sciume C., Geraci G., Iacono G., Mansueto P., 2015. High proportions of people with nonceliac wheat sensitivity have autoimmune disease or antinuclear antibodies. Gastroenterology 149, 596-603.

Cassio A., Ricci G., Baronio F., Miniaci A., BaL M., Bigucci B., Conti V., Cicognani A., 2010. Long-term clinical significance of thyroid autoimmunity in children with celiac disease. J. Pediatr. 156, 292-295.

CAtUREgli P., De Remigis A., Rose N. R., 2014. Hashimoto thyroiditis: clinical and diagnostic criteria. Autoimmun. Rev. 13, 391-397.

CHAUDHARY S., DUTTA D., KUMAR M., SAHA S., MONDAL S. A., KUMAR A., MUKHOPADHYAY S., 2016, Vitamin D supplementation reduces thyroid peroxidase antibody levels in patients with autoimmune thyroid disease. An open-labeled randomized controlled trial. Indian J. Endocrinol. Metab. 20, 391-398.

Chinthrajah S., Hernandez J. D., Boyd S., Galli S., NADEAU K., 2016. Role of IgE in autoimmunity. Asthma Immunol. 137, 984-997.

Collin P., 2005. Should adults be screened for celiac disease? What are the bene its and 
harms of screening? Gastroenterology 128, S104-S108.

Cosnes J., Cellier C., Viola S., Colombel J. F., Michaud L., Sarles J., Hugot J. P., Ginies J. L., DABAdIE A., Mouterde O. i współaut., 2008. Incidence of autoimmune diseases in celiac disease: protective effect of the gluten-free diet. Clin. Gastroentero.1 Hepatol. 6, 753-758.

De Marchi S., Chiarioni G., PRIOR M., AROSIO E., 2013. Young adults with coeliac disease may be at increased risk of early atherosclerosis. Aliment. Pharmacol. Ther. 38, 162-169.

Denham J. M., Hill I. D., 2013. Celiac Disease and Autoimmunity: Review and Controversies. Curr. Allergy Asthma Rep. 13, 347-353.

DiAmanti A., FERRETTI F., Guglielmi R., PANETTA F., Colistro F., CapPa M., Daniele A., Sole Basso M., Noto C., CRisogianni M., CASTRO M., 2011. Thyroid autoimmunity in children with coeliac disease: a prospective survey. Arch. Dis. Child. 96, 1038-1041.

Diamanti A., CAPRIATI T., BizZARRI C., FERRETTI F., ANCinelli M., Romano F., Perilli A., LAUReti F., LOCATElli M., 2016. Autoimmune diseases and celiac disease which came first: genotype or gluten? Expert Rev. Clin. Immunol. 12, 67-77.

Dilas L. T., ICIN T., PARO J. N., BAJKIN I., 2011. Autoimmune thyroid disease and other non-endocrine autoimmune diseases. Med. Pregl. 64, 183-187.

DunTAS L. H., 2009. Does celiac disease trigger autoimmune thyroiditis? Nat. Rev. Endocrinol. 5, 190-191.

DUNTAS L. H., 2015. The role of iodine and selenium in autoimmune thyroiditis. Horm. Metab. Res. 47, 721-726.

EFFRAIMIDIS G., WIERSINGA W. M., 2014. Mechanisms in endocrinology: autoimmune thyroid disease: old and new players. Eur. J. Endocrinol. 170, R241-R252.

FREEMAN H. J., 2016. Endocrine manifestations in celiac disease. World J. Gastroenterol. 22, 8472-8479.

GAEECKA M., SzACHTA P., 2013. Rola alergii pokarmowej IgG-zależnej $w$ patogenezie zmian skórnych. Dermatologia Praktyczna 6, 40-45.

GiezowsKa H., GIEZOWSKI D., 2014. Choroba trzewna - patogeneza, diagnostyka, leczenie $i$ możliwości działań profilaktycznych. Probl. Hig. Epidemiol. 95, 823-826.

GuJRAL N., FrEEMAN H. J., THOMSON A. B., 2012. Celiac disease: prevalence, diagnosis, pathogenesis and treatment. World J. Gastroenterol. 18, 6036-6059.

Honeyman M. C., STONE N. L., HaRRison L. C., 1998. T-Cell epitopes in type 1 diabetes autoantigen tyrosine phosphatase ia-2: potential for mimicry with rotavirus and other environmental agents. Molecular. Med. 4, 231-239.

KRISTJÁnsSON G., Venge P., HALLGREN R., 2007. Mucosal reactivity to cow's milk protein in coeliac disease. Clin. Exp. Immunol. 147, 449455.

LefFler D., Dennis M., George J., Kelly C., 2009. A validated disease-specific symptom index for adults with celiac disease. Clin. Gastroenterol. Hepatol. 7, 1328-1334.

LIS J., JARZĄB A., WITKOWSKA D. 2012. Rola mimikry molekularnej $w$ etiologii schorzeń o charakterze autoimmunizacyjnym, Postepy Hig Med Dosw,, 66, 475-491.

Ludvigsson J. F., BAI J. C., Biagi F., CARD T. R., CiacCi C., Ciclitira P. J., GReEN P. H., HadJIVASSILIOU M. i wspólaut., 2014. Diagnosis and management of adult coeliac disease: guide- lines from the British Society of Gastroenterology. Gut 63, 1210-1228.

Ludvigsson J. F., West J., CARD T., APpelros P., 2012. Risk of stroke in 28,000 patients with celiac disease: A nationwide cohort study in Sweden. J. Stroke Cerebrovasc. Dis. 21, 860867.

Lundin K. E., WiJmenga C., 2015. Coeliac disease and autoimmune diseasegenetic overlap and screening. Nat. Rev. Gastroenterol. Hepatol. 12, 507-515.

MCLEOD D. S., COOPER D. S., 2012. The incidence and prevalence of thyroid autoimmunity. Endocrine 42, 252-265.

Metso S., HyYTIÄ-ILMONEN H., KaUkinen K., Huhtala H., JaATinen P., SALMi J., TAURIO J., Collin P., 2012. Gluten-free diet and autoimmune thyroiditis in patients with celiac disease. A prospective controlled study. Scand. J. Gastroenterol. 47, 43-48.

Mikoś H., Mikoś M., Obara-MoszyńsKa M., NiedZIELA M., 2014. The role of the immune system and cytokines involved In the pathogenesis of autoimmune thyroid disease (AITD). Endokrynol. Pol. 65, 150-155.

MiśKIEWICZ P., KEPCZYŃSKA-NYK A., BEDNARCZUK T., 2012. Coeliac disease in endocrine diseases of autoimmune origin. Endokrynol. Pol. 63, 240-249.

Mormile R., 2016. Celiac disease and Hashimoto's thyroiditis: a shared plot? Int. J. Colorectal Dis. 31, 947.

NAIYER A. J., SHAH J., HERnANDEZ L., KIM S.Y., Ciaccio E. J., Cheng J., Manavalan S., BHAGAT G., GREen P. R., 2008. Tissue transglutaminase antibodies in individuals with celiac disease bind to thyroid follicles and extracellular matrix and may contribute to thyroid dysfunction. Thyroid 18, 1171-1178.

NICE (National Institute for Health and Clinical Excellence), 2015. Coeliac disease: recognition, assessment and management. www.nice.org. uk/guidance/ng20.

Newnham E. D., SHEPHERD S. J., STRAuss B. J., Hosking P., GIBSON P. R., 2016. Adherence to the gluten-free diet can achieve the therapeutic goals in almost all patients with coeliac disease: A 5-year longitudinal study from diagnosis. J. Gastroenterol. Hepatol. 31, 342-349.

RoY A., LASZKOWSKA M., SUNDSTRÖM J., GREEN P. H., KÄMPE O., LudVIGSSON J. F., 2016. Prevalence of celiac disease in patients with autoimmune thyroid disease: a meta-analysis. Thyroid 26, 880-890.

SANYAL D., RAYCHAUDHURI M., 2016. Hypothyroidism and obesity: An intriguing link. Indian J. Endocrinol. Metab. 20, 554-557.

Sategna-GuidetTI C., VOlTA U., Ciacci C., USAI P., CARlino A., DE Franceschi L., CAMERA A., Pelli A., Brossa C., 2001. Prevalence of thyroid disorders in untreated adult celiac disease patients and effect of gluten withdrawal: an Italian multicenter study. Am. J. Gastroenterol. 96, 751-757.

SAWICKA-GuTAJ N., WatT T., SOWIŃSKI J., GuTAJ P., WALIGÓRSKA-STACHURA P., RUCHAEA M., 2015. ThyPROpl - The Polish version of the thyroid specific quality of life questionnaire ThyPRO. Endokrynol. Pol. 66, 367-380.

SHARMA B. R., Joshi A. S., VARTHAKAVI P. K., ChadHA M. D., Bhagwat N. M., PAWAL P. S., 2016. Celiac autoimmunity in autoimmune thyroid disease is highly prevalent with a questionable impact. Indian J. Endocrinol. Metab. 20, 97-100. 
SOCHA J., CukrowskA B., 2012. Celiakia - choroba dzieci $i$ dorosłych. Przewodnik Lekarza 15, 168-174.

Spadaccino A. C., Basso D., Chiarelli S., AlberGONI M. P., D’Odorico A., Plebani M., PEDini B., Lazzarotto F., BetTerle C., 2008. Celiac disease in North Italian patients with autoimmune thyroid diseases. Autoimmunity 41, 116-121.

SWORA E., STANKOWIAK-KUlPa H., MAZUR M. 2009. Dieta bezglutenowa $w$ chorobie trzew nej. Nowiny Lekarskie 78, 324-329.

SzcZEBlowsKa D., HEBZDA A., WOJTUŃ S., 2011. Choroby autoimmunizacyjne $w$ praktyce lekar skiej. Pediatr. Med. Rodz. 7, 218-222.

SZOSTAK-WĘGIEREK D., BEDNARCZUK T., RESPONDEK W., TraczyK I., CuKrowska B., Ostrowska L., WeodareK D., JeznaCh-STEINGahen A., Bierla J., LANGE E., GAJEWSKA D., 2018. Zasadność stosowania diety bezglutenowej $w$ chorobie Hashimoto: stanowisko Grupy Ekspertów Sekcji Dietetyki Medycznej Polskiego Towarzystwa Zywienia Pozajelitowego, Dojelitowego i Metabolizmu (POLSPEN). Post. Żyw. Klin. 14, 3346.

TonutTi E., Bizzaro N., 2014. Diagnosis and classification of celiac disease and gluten sensitivity. Autoimmun. Rev. 13, 472-476.
VAlenta R., MitTermann I., Werfel T., Garn H., RENZ H., 2008. Linking allergy to autoimmune disease. Trends Immunol. 30, 109-116.

VOJDANI A., TARASH I., 2013. Cross-Reaction between gliadin and different food and tissue antigen. Food Nutrit. Sci. 4, 20-32.

WatT T., CRAMON P., HEgedüS L., BJORnER J. B., Bonnema S. J., Rasmussen A. K., FeldTRASMUSSEN U., GROENVOLD M., 2014. The Thyroid-Related Quality of Life Measure Thypro has good responsiveness and ability to detect relevant treatment effects. J. Clin. Endocrinol. Metabol. 99, 3708-3717.

WichMAN J., WinTHER K. H., BONNEMA S. J., HEGEDÜS L., 2016. Selenium supplementation significantly reduces thyroid autoantibody levels in patients with chronic autoimmune thyroiditis: a systematic review and meta-analysis. Thyroid 26, 1681-1692.

ZAKRZEWSKA E., ZEGAN M., MichOTA-KATUlSKA E., 2015. Zalecenia dietetyczne $w$ niedoczynności tarczycy przy wspólwystępowaniu choroby Hashimoto. Bromat. Chem. Toksykol. 48, 117-127.

KOSMOS Vol. 68, 2, 215-226, 2019

Sebastian Konieczny, Ewa Lange, Jolanta Krusiec

Department of Dietetics, Faculty of Human Nutrition and Consumer Sciences, 159C Nowoursynowska Str., 02-776 Warszawa,

E-mail: ewa_lange@sggw.pl

\section{THE INFLUENCE OF ELIMINATIONAL DIET ON THE QUALITY OF LIFE OF PERSONS WITH SELECTED AUTOIMMUNE DISEASES}

\section{Summary}

The complexity of the etiopathogenesis of autoimmune diseases, including celiac disease and Hashimoto's disease, and the lack of effective pharmacotherapy means that proper dietotherapy may be an important factor in improving health and living comfort, as well as reducing the development of complications. In order to check this supposition retrospective questionnaire studies were conducted for a group of 209 participants aged from 18 to 60 years, including 81 women with Hashimoto and 106 women and 12 men with celiacia desease. Their statistically validated results showed that one third of people with celiac disease, in addition to excluding gluten grains, eliminated dairy products from the diet. Most people with Hashimoto's disease excluded gluten grains from the diet, and more than half also dairy products and soy. The greatest improvement in health, in particular the reduction in the occurrence of nausea, bloating, pain and increased feeling of comfort were observed by people with celiac disease in addition to gluten grains: milk and its products, nuts and soy. Similarly, the largest changes in the symptoms of Hashimoto's disease, in particular the reduction of hypersensitivity to temperature, skin dryness and improvement of well-being were declared by people eliminating gluten cereals, dairy products, peanuts and nightshade vegetables. Treatment of celiac disease based on a gluten-free diet combined with the elimination of nuts and soy may bring benefits associated with a greater improvement in health and quality of life, and the elimination of gluten cereals and peanuts can help to improve the quality of life of people with Hashimoto's disease. 